\title{
IMPACT OF THREE APPLICATION METHODS OF SPINOSAD IN THE MANAGEMENT OF Callosobruchus maculatus (FABR.) (COLEOPTERA: BRUCHIDAE)

\author{
Abouelkassem, SH. A. A. ${ }^{1}$; A. A. Mohamed ${ }^{2}$; N. M El- \\ Taweelah $^{2}$ and Naglaa, M, I. Youssef ${ }^{2}$ \\ 1- Faculity of Agriculture, Al-Azhar University, Assiut \\ 2- Plant Protection Research Institute, Dokiki, Giza, Egypt.
}

\begin{abstract}
Cowpea beetle, Callosobruchus maculatus (Fabr.) is considered the most important pest of cowpea, Vigna unguiculata (L.) Walp., stored in tropical and sub tropical regions. Laboratory bioassays were carried out in order to evaluate the effectiveness of spinosad (Tracer $24 \%$ SC) by using three application methods, contact, fumigant and repellent toxicity, against the cowpea beetle $C$. maculates. Regarding to the contact toxicity, when spinosad applicated by thin film residue in petri dishes $\left(9 \mathrm{~cm}^{2}\right.$ diameter) its LC50s and LC90s recorded 122.55 and $1285.88 \mathrm{ppm}$, respectively, comperated with 645.06 and $3884.36 \mathrm{ppm}$, for grain mixing method after $24 \mathrm{~h}$. The percentage of hatching eggs varied from 40.60 to $71.90 \%$, while the numbers of emerged adults ranged from 10 to 81 insects, comperated with 299 for control. The reduction of progeny ranged from 70.07 to 100.00 with 250 and 1500 $\mathrm{ppm}$. The Main development period (period of generation) ranged from 38.00 to 60 day comperated with 24 days for control. Application of spinosad as fumigant recorded 224.599 and $1464.980 \mathrm{ppm}\left(50 \mathrm{~cm}^{3}\right)$, for LC50s and LC90s, respectively. The repellent activity of spinosad by two applications methods resulted $100 \%$ percentage repellency for adults at concentrations of 300 and $750 \mathrm{ppm}$ for petri dish and jar techniques, respectively. Spinosad may be a good choice as a potent boinsecticide by thin residue film method against studied stored product insect $C$. maculatus .
\end{abstract}

Keywords: Cowpea beetle, spinosad, Stored grain Toxic, Repellent action

\section{INTRODUCTION}

Spinosad is an insecticide product from Dow Agro Sciences (Indianapolis, Indiana, U.S.A.), derived via fermentation from a naturallyoccurring soil actinomycete, Saccharopolyspora spinosa (Bacteria: Actinobacteridae). Spinosad contains two insecticidal factors, spinosyns A and $\mathrm{D}$, present in an approximately $85: 15 \%$ ratio in the final product (Sparks et al., 1999). Spinosad is highly active by both contact and ingestion to numerous pests in the orders Lepidoptera, Diptera, Thysanoptera, Coleoptera, Orthoptera, Hymenoptera, and others (Bret et al., 1997). It affects nicotinic acetylcholine and gamma amino butyric acid (GABA) receptors sites of the insect nervous system, and so far has proved non-cross resistant to any other known insecticide (Salgado and Sparks,2005).In addition, spinosad exhibits low mammalian toxicity and a highly favorable environmental profile(Cleveland et al.,2001).Spinosad is considered a natural product and thus approved for use in organic agriculture by numerous national and international certification bodies(Cleveland,2007).Spinosad suitability as a stored grain protectant has been progressively highlighted in a series of scientific publications dating from 1999(Subramanyam et al.,1999, 2003;Mutambuki et al.,2002).Since then,spinosad has been shown to provide highly 
effective and long-lasting control of numerous key stored product pests on various seeds (Toews et al., 2003; Chintzoglou et al., 2008). One of the main problems that occur during storage is the attack of insect pests, notably the cowpea C. maculatus. (Sanon et al., 2002). The losses arise from larvae penetration and feeding within the seeds, which leads to weight loss, as well as lower nutritional value, germination potential and cleanliness (Barbosa et al., 2002). In addition, the mite infestation and infection by micro organisms, especially fungi, contribute to the increase of the grain mass temperature, affecting the product's quality (Sari et al., 2003). Chemical control with protect synthetic insecticides (organophosphates and pyrethroids) and fumigants (phosphine) is a common practice used to control pests of stored seeds. However, due to the accumulation of residues in seeds, the selection of resistant insect population and other side effects, alternative approaches in Integrated Pest Management (IPM) have been considered. In this context several biotic agents and constituent bioactive substances, also called bio-insecticides, have been tested and considered promising for the control of agricultural and urban pests (Arruda and Batista, 1998; Martinazzo et al., 2000; Kemabonta and Odebiyi, 2005). Control of stored product insects is best achieved through an integration of physical, chemical, and biological methods (Hagstrum et al., 1999; Phillips and Throne, 2010). However, in practice there is still a strong reliance on the use of chemicals applied to seeds at the time of storage. These chemicals are known as grain protectants and they provide protection to stored seeds for 4 to 12 months of storage. To control an existing infestation, especially in grain that is not treated with a protectant, fumigants such as phosphine are used. Existing chemical control products are few, and of these many are under intense scrutiny due to concerns about human safety, insect resistance, environmental impacts, and presence of chemical residues in raw and processed foods (Daglish, 2006). Alternative chemical control options to protect grain that do not suffer from the concerns outlined above are urgently needed, and spinosad is one such product that fills this void. After global launch imminent, this paper attempt to estimate toxicity of spinosad in different three application methods, contact, fumigant and repellent effect against one from serious stored product insects, the cowpea beetle C. maculatus.

\section{MATERIALS AND METHODS}

Bioinsecticide: Spinosad (Tracer $24 \%$ Suspension concentrate) Source: Nile valley for Agricultural Development, Giza, Egypt. Insects:

The experiments were conducted at the Laboratory of Agricultural Research Station, Sakha, Department of Stored Product Insects, at $28.5 \pm$ $1.6 \mathrm{C}^{\circ}, 52.6 \pm 7.4 \%$ relative humidity and $12 \mathrm{~h}$ photophase. The insects were reared for several generations in cowpea $\mathrm{cv}$. and maintained for the next experiments. The seeds packed in glass containers closed with perforated plastic lids lined on the inside with a fine cloth to allow gas exchange. They were confined for three days for oviposition, before being removed. The containers were stored until the emergence of the F1 generation. Clean and dry seeds, used for experiments, were placed in plastic bags and kept in a freezer at $-10{ }^{\circ} \mathrm{C}$ for seven days, to eliminate possible insect infestation from the field. Then, the seeds were transferred to glass fasks and kept in the laboratory for 10 days in order to reach the equilibrium moisture content. 


\section{Contact toxicity tests filter paper method:}

The contact toxicity on filter papers was conducted using filter paper discs (Whatman No. 1, $9 \mathrm{~cm}$ diameter) (Tapondjou et al., 2005). Spinosad was tested at concentrations of 100, 200,300, 400 and $500 \mathrm{ppm} / \mathrm{cm}^{2}$, and 1 $\mathrm{mL}$ of each solution was dispensed on the surface of the paper that was then placed in glass petri dishes. After $10 \mathrm{~min}$, once the solvent had been evaporated, 10 unsexed adults were deposited into each disc and stored in darkness at $26 \pm 2{ }^{\circ} \mathrm{C}$ and $70-85 \% \mathrm{RH}$ (Olivero-Verbel et al., 2010). Three replicates were used for each concentration, repeating each assay twice. Mortality was recorded after $24 \mathrm{~h}$. Insects were considered dead when no leg or antennal movements were recorded.

\section{Grain mixing method:}

Preliminary tests were performed to define the concentrations of spinosad (250, 500, 750, 1000 and $1500 \mathrm{ppm} / 20 \mathrm{~g}$ seeds). Each treatment consisted of $20 \mathrm{~g}$ of cowpea cv. seeds infested with ten female of $C$. maculatus (1-3 day old) packed in $250 \mathrm{~mL}$ glass containers with a perforated lid, coated with thin fabric (voile) to allow gas exchange (Mutambuki, K. et al, 2002). The concentrations of spinosad were added to the seeds with an automatic pipettor, in glass containers, and subjected to manual agitation for $2 \mathrm{~min}$. After 24, 48, $72 \mathrm{~h}$ from the experiment assembly, mortality percentages were evaluated. Eggs were counted at 12 days and the insects hatched 23 days after confinement. The lethal concentrations (LC50 and LC90) of spinosad were estimated using the Probit analysis program (Finney 1971).

\section{Fumigant toxicity tests:}

Fumigation bioassays without seeds were carried out with 10 adults exposed in $50 \mathrm{ml}$ conical flasks sealed with glass adaptors fitted with injection septa. Filter papers (Whatman Number 1) were placed below the septa to capture the injected spinosad and to produce a large surface area for evaporation. (Arruda and Batista (1998). Each flask had its volume measured by the amount of water it could contain. Different volumes concentrations (V/ V) of bio- insecticide spinosad were injected through the septa into the conical flasks using a gas syringe. Flasks were held at $28.0 \pm 1.0{ }^{\circ} \mathrm{C} \& 60.0$ $\pm 5.0 \%$ R.H in a constant temperature room during the exposure periods. At least 5 concentrations were tested from 100 to $500 \mathrm{ppm} / \mathrm{cm}^{2}$. Three replicates were prepared for each concentration and control. Adults of $C$. maculatus (1-3 day old) were exposed to treatments for 24, 48 and 72 hours for each concentration. After each exposure period, insects were removed and put into clean vials and mortality determined immediately. Similar units, without spinosad used as control containing the same number of insect and maintained at the same conditions. Insect showing any movement were considered to be alive. Mortality counts were recorded at the same exposure periods that conducted in treatments. The percentage mortality was calculated after each exposure period for each concentration by Abbott's equation (1925). The LC 50 and LC 90 values were calculated by probit analysis (Finney 1971). 


\section{Repellent effect tests \\ Petri dishes method:}

The repellent activity was measured using the area preference method (Olivero-Verbel et al., 2010). A volume of $0.5 \mathrm{~mL}$ of spinosad was uniformly applied to a half-filter paper disk to obtain the desired spinosad volume per unit area of $100,200,300,400$ and $500 \mathrm{ppm} / \mathrm{cm}^{2}$. The other half of the filter paper was treated with an equal volume of water as a vehicle control. Test areas consisted of $9 \mathrm{~cm}$ Whatman No. 1 filter paper cut in half. The treated and control half disks were air-dried for $10 \mathrm{~min}$ to remove the solvent, re-attached with adhesive tape, and kept in $90 \mathrm{~mm}$ glass Petri dishes. Ten adults of $C$. maculatus of both sexes were released at the centre of each filter paper disk. Dishes were covered and placed in darkness at $26 \pm$ $2{ }^{\circ} \mathrm{C}$ and relative humidity of $70-85 \%$. The numbers of $C$. maculatus specimens on treated and untreated portions of the experimental paper halves were counted for each dish after 2, 8 and $12 \mathrm{~h}$ exposure. Percentage repellency (PR) for a given treatment time was obtained using the formula: $\mathrm{PR}=\left[\left(\mathrm{Nc}{ }_{-} \mathrm{Nt}\right) /(\mathrm{Nc}+\mathrm{Nt})\right] \times 100$, where $\mathrm{Nc}$ and $\mathrm{Nt}$ were the number of insects on the untreated (control) and treated areas, respectively. Three replicates were used for each tested concentration of spinosad, and each assay was repeated twice.

jar method:

Concentrations 250, 500, 750, 1000 and 1500 ppm of spinosad were tested. Bioassays were conducted in arenas made of two $120 \mathrm{~mL}$ plastic containers connected to a central plastic box through plastic tubes. In one of the boxes, $20 \mathrm{~g}$ of cowpea seeds cv. without the spinosad (control) was placed (Tapondjou, et al. 2005). The same amount of seeds impregnated with the respective concentrations of spinosad were placed in the other box. Ten adults of $C$. maculatus (1- 3 day old), were released in the central box. The completely randomized design was used with two treatments (concentration of spinosad and control) and 10 repetitions. After 2, 8 and 12 $h$, the insects attracted to each box were counted and discarded, and the seeds transferred to other plastic containers. Percentage repellency (PR) for a given treatment time was obtained using the formula: $\mathrm{PR}=\left[\left(\mathrm{Nc}{ }_{-} \mathrm{Nt}\right) /(\mathrm{Nc}\right.$ $+\mathrm{Nt})] \times 100$, where $\mathrm{Nc}$ and $\mathrm{Nt}$ were the number of insects on the untreated (control) and treated areas, respectively. Three replicates were used for each tested concentration of spinosad, and each assay was repeated twice.

\section{RESULTS AND DISCUSSION}

\section{Contact toxicity tests}

Petri dishes method: According to Table 1, the LC50s LC90s of the spinosad recorded 122.55 and $1285.88 \mathrm{ppm} / \mathrm{cm}^{2}$, respectively. Mortality rate of $C$. maculatus, adults, increased with the increase of concentrations. The results of upper confidential level (UCL) and lower confidential level (LCL) values are $24.410-188.408$ and $622.45-40366.29$ for LC50s and LC90s, recpectively. 
Table (1):Toxicity ratios and lethal concentration of spinosad applied by contact methods (thin film) on adults of C. maculatus. after $24 \mathrm{~h}$.

\begin{tabular}{|c|c|c|c|c|c|c|c|}
\hline $\begin{array}{l}\text { Conc } \\
\text { (ppm) }\end{array}$ & $\begin{array}{c}\text { Mortality } \\
\%\end{array}$ & Slope & $\begin{array}{c}\text { LC } 50 \\
\left(\mathrm{ppm} / \mathrm{cm}^{2}\right)\end{array}$ & $\begin{array}{c}\mathrm{CL} \\
\mathbf{9 5 \%}\end{array}$ & $\begin{array}{c}\mathrm{LC} 90 \\
\left(\mathrm{ppm} / \mathrm{cm}^{2}\right)\end{array}$ & $\begin{array}{c}\mathrm{CL} \\
\mathbf{9 5 \%}\end{array}$ & $x^{2}$ \\
\hline 100 & 46.60 & \multirow{5}{*}{1.255} & \multirow{5}{*}{122.55} & \multirow{5}{*}{$\begin{array}{l}24.410 \\
188.408\end{array}$} & \multirow{5}{*}{1285.88} & \multirow{5}{*}{\begin{tabular}{|l}
622.45 \\
40366.29
\end{tabular}} & \multirow{5}{*}{-1.623} \\
\hline 200 & 60.00 & & & & & & \\
\hline 300 & 66.67 & & & & & & \\
\hline 400 & 73.73 & & & & & & \\
\hline 500 & 80.00 & & & & & & \\
\hline
\end{tabular}

Grain mixing method:

According to Table 2, the LC50s LC90s of the toxicity recorded 645.06 and 3884.36 ppm, respectively. Mortality rate of $C$. maculatus. Adults, increased with the increase of concentrations tested. The results of upper confidential level (UCL) and lower confidential level (LCL) values are 453.15 - 886.532 and 2087.42 - 21766.45 for LC50s and LC90s, recpectively.

Table (2): Toxicity ratios and lethal concentration of spinosad applied by contact methods (mixing with feeding medium) on adults of C. maculatus. after $24 \mathrm{~h}$.

\begin{tabular}{|c|c|c|c|c|c|c|c|}
\hline $\begin{array}{l}\text { Conc } \\
\text { (ppm) }\end{array}$ & $\begin{array}{c}\text { Mortality } \\
\%\end{array}$ & Slope & $\begin{array}{c}\text { LC } 50 \\
\text { (ppm/20 g } \\
\text { seeds) }\end{array}$ & $\begin{array}{c}\text { CL } \\
95 \%\end{array}$ & $\begin{array}{c}\text { LC } 90 \\
\text { (ppm/20 g } \\
\text { seeds) }\end{array}$ & $\begin{array}{l}\text { CL } \\
95 \%\end{array}$ & $x^{2}$ \\
\hline 250 & 26.67 & \multirow{5}{*}{1.64} & \multirow{5}{*}{645.06} & \multirow{5}{*}{$\begin{array}{l}453.15- \\
886.532\end{array}$} & \multirow{5}{*}{3884.36} & \multirow{5}{*}{$\begin{array}{l}2087.42- \\
21766.45\end{array}$} & \multirow{5}{*}{0.583} \\
\hline 500 & 43.33 & & & & & & \\
\hline 750 & 50.00 & & & & & & \\
\hline 1000 & 60.00 & & & & & & \\
\hline 1500 & 76.67 & & & & & & \\
\hline
\end{tabular}

CL: Confidence limits at $95 \%$.

$\mathrm{X}^{2}:$ Sum squares

The results for the number of eggs and emerged insects indicated that, in general, the higher concentration caused the higher mortality of spinosad, the lower number of eggs and emerged insects in Table 3. Studies have shown that bio-insecticide tested can effectively control eggs, larvae, pupae and adults of C. maculatus. Spinosad at concentrations of 100, 200, 300,400 and 600 ppm resulted in 35.63, 52.03, 61.64, 68.08 and $72.74 \%$ mortality of adults, respectively, the corresponding viable eggs values were, $131,94,61,30$ and 19 eggs (344 for control), respectively. The percentages hatched eggs listed in table 3 were 71.9, 63.5, 57.23, 43.27 and $40.6 \%$ hatched. (85.1\% for control). The number of emerged adults were, 81,57 , 35,10 and 00.00 ( 299 for control). The percentages of emerged adults were, $61.8,61.4,57.17,37.17$ and $00.00 \%$ emerged adults. (86.93\% for control). The percentages reduction of progeny were, $70.07,81.17,88.43,96.37$ and $100.00 \%$ reduction. Spinosad at $600 \mathrm{ppm}$ resulted in $100 \%$ mortality of adults besides reducing viable eggs and emerged insects by $100 \%$. 
Table (3):Offespring reduction (\%) of $C$. maculatus in cowpea seeds treated with spinosad applied by grain mixing method.

\begin{tabular}{|c|c|c|c|c|c|c|c|}
\hline Conc & $\begin{array}{c}\text { T.N of } \\
\text { hatche } \\
\text { d eggs }\end{array}$ & $\begin{array}{c}\% \\
\text { hatcha } \\
\text { bility }\end{array}$ & $\begin{array}{c}\text { T.N of } \\
\text { adult } \\
\text { emergance }\end{array}$ & $\begin{array}{c}\% \text { of } \\
\text { adult } \\
\text { emergance }\end{array}$ & $\begin{array}{c}\% \text { adult } \\
\text { reduction }\end{array}$ & $\begin{array}{c}\text { Productively } \\
\text { index }\end{array}$ & $\begin{array}{c}\text { Main } \\
\text { development } \\
\text { period }\end{array}$ \\
\hline 250 & 131.00 & 71.90 & 81.00 & 61.80 & 70.07 & 84.77 & 38.00 \\
\hline 500 & 94.00 & 63.5 & 57.00 & 61.40 & 81.17 & 74.87 & 40.00 \\
\hline 750 & 61.00 & 57.23 & 35.00 & 57.17 & 88.43 & 67.37 & 40.00 \\
\hline 1000 & 30.00 & 43.27 & 10 & 37.77 & 96.37 & .50 .80 & 51.00 \\
\hline 1500 & 19.00 & 40.60 & 0.00 & 100.00 & 100.00 & 100.00 & 60.00 \\
\hline $\begin{array}{c}\text { Cont } \\
\text { rol }\end{array}$ & 344.00 & 85.10 & 299.00 & 86.93 & -- & -- & 24.00 \\
\hline
\end{tabular}

${ }^{a} \mathrm{PR}=\left[\left(\mathrm{NC} \_\mathrm{NT}\right) /(\mathrm{NC}) \times 100\right]$ as $\mathrm{PR}=$ percentage of oviposition reduction; $\mathrm{NC}=$ number of eggs in the control and NT = number of eggs in the treatment.

\section{Fumigant toxicity tests:}

According to Table 4, the LC50s LC90s of the spinosad recorded 224.599 and $1464.980 \mathrm{ppm}$, respectively. Mortality rate of C. maculatus adults increased with the increase of concentrations tested. The results of upper confidential level (UCL) and lower confidential level (LCL) values are 142.366 - 306.714 and 865.47 - 4783.849 for LC50s and LC90s, recpectively.

Table (4): Toxicity ratios and lethal concentration of spinosad applied by fumigant methods.on adult C. maculatus. after $24 \mathrm{~h}$.

\begin{tabular}{|c|c|c|c|c|c|c|c|}
\hline $\begin{array}{l}\text { Conc } \\
\text { (ppm) }\end{array}$ & $\begin{array}{c}\text { Mortality } \\
\%\end{array}$ & Slope & $\begin{array}{l}\text { LC 50 } \\
\text { (ppm) }\end{array}$ & $\begin{array}{c}\mathrm{CL} \\
95 \%\end{array}$ & $\begin{array}{l}\text { LC 90 } \\
\text { (ppm) }\end{array}$ & $\begin{array}{c}C L \\
95 \%\end{array}$ & $\mathrm{X}^{2}$ \\
\hline 100 & 30.00 & \multirow{5}{*}{1.57} & \multirow{5}{*}{224.599} & \multirow{5}{*}{$\begin{array}{l}142.366 \\
306.714\end{array}$} & \multirow{5}{*}{-1464.980} & \multirow{5}{*}{$\begin{array}{l}865.47 \\
4783.849\end{array}$} & \multirow{5}{*}{-0.237} \\
\hline 200 & 46.67 & & & & & & \\
\hline 400 & 63.33 & & & & & & \\
\hline 600 & 73.33 & & & & & & \\
\hline 800 & 83.33 & & & & & & \\
\hline
\end{tabular}

CL: Confidence limits at $95 \%$.

$\mathrm{X}^{2}$ : Sum squares

\section{Repellent activity of spinosad \\ Petri dishes.}

The repellent activity of spinosad was increased when insects were exposed for a longer time. Spinosad showed repellent activity to C.maculatus adults when applied by petri dish method at concentrations ranging from 100 to $500 \mathrm{ppm} / \mathrm{cm}^{2}$ during 2, 8, $12 \mathrm{~h}$ of exposure. After $2 \mathrm{~h}$, the PR values for these five concentrations ranged from 20 to $100 \%$. The previous values were recorded 60 to $100 \%$ at $8 \mathrm{~h}$ of exposure. After $12 \mathrm{~h}$ of exposure the PR values resulted 93.33 to $100 \%$.(Table 5). 
Table (5): Repellent effect of spinosad on adults of $C$. maculatus in Petri dishes. without feeding medium.

\begin{tabular}{|l|c|c|c|c|c|c|c|c|c|}
\hline \multirow{3}{*}{ Conc } & \multicolumn{9}{|c|}{ Adult individual attracted } \\
\cline { 2 - 10 } & \multicolumn{3}{|c|}{ After 2 h } & \multicolumn{3}{c|}{ After 8 h } & \multicolumn{3}{c|}{ After 12 h } \\
\cline { 2 - 10 } & Control & spinosad & PR & Control & Spinosad & PR & Control & spinosad & $\begin{array}{c}\text { PR } \\
\%\end{array}$ \\
\hline 100 & 18 & 12 & 20 & 24 & 6 & 60 & 29 & 1 & 93.33 \\
\hline 200 & 24 & 6 & 60 & 30 & 0.00 & 100 & 30 & 0.00 & 100 \\
\hline 300 & 27 & 3 & 80 & 30 & 0.00 & 100 & 30 & 0.00 & 100 \\
\hline 400 & 30 & 0.00 & 100 & 30 & 0.00 & 100 & 30 & 0.00 & 100 \\
\hline 500 & 30 & 0.00 & 100 & 30 & 0.00 & 100 & 30 & 0.00 & 100 \\
\hline
\end{tabular}

PR (percentage repellency) = NC-NT/ $(\mathrm{NC}+\mathrm{NT}) \times 100,=\%$, where Nc and Nt were the number of insects on the untreated (control) and treated areas, respectively.

\section{Jar methods}

The repellent activity of spinosad was increased when insects were exposed for a longer time. Spinosad showed repellent activity to C.maculatus adults when applied by jar method at concentrations ranging from 250 to $1500 \mathrm{ppm} / \mathrm{cm}^{2}$ during 2, $8,12 \mathrm{~h}$ of exposure. After $2 \mathrm{~h}$, the PR values for these five concentrations ranged from 6.67 to $100 \%$. The previous values were recorded 33.33 to $100 \%$ at $8 \mathrm{~h}$ of exposure. After $12 \mathrm{~h}$ of exposure the PR values resulted 66.67 to $100 \%$.(Table.6).

Table (6): Repellent effect of spinosad on adult $C$. maculatus in cowpea seeds supplied with feeding medium.

\begin{tabular}{|c|c|c|c|c|c|c|c|c|c|}
\hline \multirow{3}{*}{$\begin{array}{l}\text { Conc } \\
\text { ppm }\end{array}$} & \multicolumn{9}{|c|}{ Adult individual attracted } \\
\hline & \multicolumn{3}{|c|}{ After $2 \mathrm{~h}$} & \multicolumn{3}{|c|}{ After $8 \mathrm{~h}$} & \multicolumn{3}{|c|}{ After $12 \mathrm{~h}$} \\
\hline & Control & spinosad & $\begin{array}{c}\text { PR } \\
\%\end{array}$ & control & spinosad & $\begin{array}{c}\text { PR } \\
\%\end{array}$ & Control & spinosad & $\begin{array}{c}\text { PR } \\
\%\end{array}$ \\
\hline 250 & 16 & 14 & 6.67 & 20 & 10 & 33.33 & 25 & 5 & 66.67 \\
\hline 500 & 2 & 10 & 33.33 & 25 & 5 & 66.67 & 29 & 1 & 93.33 \\
\hline 750 & 22 & 8 & 46.67 & 28 & 2 & 86.67 & 30 & 0.00 & 100 \\
\hline 1000 & 30 & 0.00 & 100 & 30 & 0.00 & 100 & 30 & 0.00 & 100 \\
\hline 1500 & 30 & 0.00 & 100 & 30 & 0.00 & 100 & 30 & 0.00 & 100 \\
\hline
\end{tabular}

PR (percentage repellency) $=\mathrm{NC}-\mathrm{NT} /(\mathrm{NC}+\mathrm{NT}) \times 100,=\%$, where $\mathrm{Nc}$ and $\mathrm{Nt}$ were the number of insects on the untreated (control) and treated areas, respectively.

Beeman and Speirs (1986) found that avermectin $B_{1}$ (Abamectin) was extremely effective against 6 beetles and 3 moth pests of stored products. At dose $320 \mathrm{ppb}$ in wheat, all adults of 3 species of Coleoptera were killed in 3 weeks. For most of the Coleoptera and Lepidoptera, 96-100\% Suppression of progeny was achieved at doses of 10-160ppb. Abo Arab and El-Hamady (1998) carried out studies to evaluate the efficiency of avermectin as a protectant against three important stored grain insects, namely, the rust red flour beetle, Tribolium castaneum (Herbest); the rice weevil, Sitophilus oryzae L. and the cowpea weevil, Callosobruchus maculatus F. using the technique of exposure to feeding medium. Avermectin exhibited considerable toxicity nearly equal to that of malathion. C. maculatus showed the highest susceptibility to avermectin followed by S. oryzae and T. castaneum (LC50's 
$0.094,1.18$ and $1.75 \mathrm{mg}$ a.i./100 gm of grain, respectively). The compound also showed potential toxicity to the immature stages inducing reduction in the progeny. Thus, number of offspring and number of eggs (laid by $C$. maculatus) or their hatchability were greatly reduced. Subramanyam et al. (2003) carried out laboratory and field tests on wheat and maize have shown that spinosad is effective against the lesser grain borer (Rhizopertha dominica), rice weevil (S. oryzae), flat grain beetle (Cryptolestes pusillus), rusty grain beetle (Cryptolestes ferrugineus), confused flour beetle (Tribolium confusum) and larvae of the Indian mill moth (Plodia interpunctella) at 1 $\mathrm{mg} / \mathrm{kg}$ grain. Flinn et al. (2004) evaluated the effects of controlled aeration and a commercial biological insecticide, spinosad in suppressing insect populations in stored wheat. They stated that is the first report comparing the field efficacy of spinosad and aeration in managing insects in farm bins, they suggest that spinosad is very effective in suppressing $R$. dominica and $T$. castaneum populations in stored wheat. Many research workers determined the efficacy of spinosad (a biopesticide) in laboratory bioassays against a range of stored product insect species (Daglish and Nayak, 2005; Kljajic and Peric, 2007; Daglish (2008), Athanassion et al. (2009). El-Madawy (2013) evaluated spinosad as contact, repellent and fumigant agent against $T$. castaneum and $R$. dominica in laboratory. She reported that spinosad was effective against the two tested insect species at the all rates of concentration and exposure periods. Mortaliy increased with the increasing of concentration and exposure periods with the tested insects where $12.5 \mathrm{ppm}$ of spinosad acheved 9 and $23 \%$ mortality after 24 and $72 \mathrm{~h}$ of treatment, while \% mortality reached 37 and $87 \%$ at 24 and $72 \mathrm{~h}$ by $100 \mathrm{ppm}$ with $T$. castaneum post-treatment. Also, the percentage repellency ranged from 74 to $34 \%$ and 94 to $100 \%$ against $T$. castaneum and $R$. dominica through the time of exposure $(24 \mathrm{~h})$, respectively. For spinosad as fumigant agent, El-Madawy (2013) found that spinosad had an insecticidal effect on $R$. dominica increased with the increasing of concentrations and exposure periods while the same insecticide does not have any effect on $T$. castaneum adults at the tested concentration. Also, spinosad completely prevented laying eggs till four weeks after treatment for $T$. castaneum. We reviewed the previous available references which have not included the fumigation and repellent methods according to our information, but we conducted those methods (repellent and fumigation) to evaluate their action as two common bioassay techniques where the current laboratory experiments were conducted to select the suitable method for controlling cowpea beetle, $C$. maculatus which attacks some of the important legume seeds in field and through storage. Three bioassay investigations were used for this purpose, contact (thin film residue and feeding medium mixing), repellent and fumigation techniques. Our findings obtained clearly showed that the bioinsecticide spinosad achieved a good potency against $C$. maculatus with the all tested methods and levels of concentrations. A different action was found between the three techniques due to the type of application where contact with spinosad deposit varied from one method to another. Through exposure of an insect to the spinosad residue, it picks different amounts of insecticide (more or little) according to the method used. In this study, the contact method (thin film) 
exhibited the highest action against $C$. maculatus followed by feeding medium mixing and fumigation. Although fumigation method had the lower effect (based on LC50) we lean to applicate this method since it minimizes direct grain pollution and kills the immature stages either inside grain or outside. Finally, consequently, the current study suggested that spinosad may comply well with the criteria of the proper protectant against stored grain insects.

\section{CONCLUSION}

The present results confirmed the importance of using spinosad as a promising alternative for the management of C.maculatus in stored cowpea seeds, since the release of use for this compound is more easily obtained. The contact, fumigation and repellency effects, combined with low mammalian toxicity, rapid degradation in the environment, efficiency in pest control and safety for applicators and consumers, reopen the need for continued research on spinosad.

\section{Acknowledgments}

The authors thank the staff of the Department of Stored Product Pests, Plant Prot. Res. Inst., Sakha Agric. Res. Station, for their assistance and support in the laboratory experiments. Special thanks for Professor Raafat Abou Arab for reviewing of this paper.

\section{REFERENCES}

Abbott, W. S. (1925). A method of computing the effectiveness of insecticides. .J. Econ.Entomo!'; 18,2: 265-267.

Abo-Arab, R.B.S. and Sh.E.E. El-Hamady (1998). Avermectin as a protectant against stored grain insects. Alex. Sci. Exch. 19: 419-427.

Arruda, F.P.,and, J.L., Batista (1998). Efeito da luz, de oleos vegetais e de cultivares de caupina infestação do caruncho Callosobruchus maculatus (Fabr., 1775) (Coleoptera: Bruchidae). Revista Caatinga 11, 53-55.

Athanassiou, Ch.G.; F.H. Arthur and J.E. Throne (2009). Efficacy of spinosad in layer treated wheat against five stored product insect species. J. Stored Prod. Res., 45(4): 236-240.

Barbosa, F.R., M.Yokoyama, P.A.A.,Pereira and, F.J.P., Zimmermann (2002). Controle do caruncho-do-feijoeiro Zabrotes subfasciatus com 1007acul vegetais, munha, materiais inertes e malathion. Pesquisa Agropecuária Brasileira 37, 1213-1217.

Beeman, R.W. and W.E. Speries (1986). Toxicity, persistence and antagonism of avermectin B1 against stored product insects. Proceedings of the 3rd International Working Conf. on Stored Product Entomol. October 23-28, 1983, Kansas State University, Manhattan, Kansas, USA. 
Bret, B.L., L.L Larson., J.R., Schoonover, , T.C., Sparks and G.D., Thompson, (1997). Biological properties of spinosad. Down to Earth 52, 6-13.

Chintzoglou, G., C.G., Athanassiou, and , F.H., Arthur (2008). Insecticidal effect of spinosad dust, in combination with diatomaceous earth, against two stored-grain beetle species. Journal of Stored Products Research 44, 347-353.

Cleveland, C.B., M.A., Mayes, S.A., Cryer, (2001). An ecological risk assessment for spinosad use on cotton. Pest Management Science 58, 70-84.

Cleveland, C.B., (2007). Environmental and health assessments for spinosad against the backdrop of organic certification. In: Felsot, A.J., Racke, K.D. (Eds.), Certified Organic and Biologically-Derived Pesticides: Environmental, Health, and Efficacy Assessment. Symposium Series. American Chemical Society, Washington D.C., pp. 109-130.

Daglish, G.J. and M.K. Nayak (2005). Spinosad is an effective grain protectant against resistant strains of Rhyzopertha dominica (F.). International Pest Control, 47(3): 130-132.

Daglish, G.J., (2006). Opportunities and barriers to the adoption of potential new grain protectants and fumigants. In: Lorini, I., Bacaltchuk, B., Beckel, H.,Deckers, D., Sundfeld, E., dos Santos, J.P., Biagi, J.D., Celaro, J.C., Faroni, L.R.D.'A., Bortolini de, O.F.L., Sartori, M.R., Elias, M.C., Guedes, R.N.C., da Fonseca, R.G., Scussel, V.M. (Eds.), Proceedings of the 9th International Working Conference for StoredProduct Protection, 15-18 October 2006. ABRAPOS, Campinas, Säo Paulo, Brazil, pp. 209-216.

Dagllsh, G.J. (2008). Impact of resistance on the efficacy of binary combinations of spinosad, chlorpyrifos-methyl and S-methoprene against five stored-grain beetles. J. Stored Prod. Res. 44(1): 71-76.

El-Madawy, Al-Zahraa, A.E. (2013). Studies on certain insect pests attacking some stored seeds. M.Sc. Thesis, Fac. Agric., Mansoura Univ.

Finney, D.I (1971). Probit analysis, 3rded,. Cambridge University Press, London. $333 \mathrm{P}$.

Flinn, P.W.; B. Subramanyam and F.H. Arthur (2004). Comparison of aeration and spinosad for suppressing insects in stored wheat. J. Econ. Entomol. 97(4): 1465-1473.

Hagstrum, D.W., C., Reed, P.Kenkel (1999). Management of stored wheat pests in the USA. Integrated Pest Management Reviews 4, 127-142.

Kemabonta, K.A., and, J.A., Odebiyi (2005). Susceptibility of the life stages of Callosobruchus maculatus Fab. (Coleoptera: Bruchidae) to diflubenzuron in cowpea seeds. Journal of Plant Diseases and Protection 112, 193-199.

Kljajic, P. and I. Peric (2007). Effectiveness of wheat-applied contact insecticides against Sitophilus granarius (L.) originating from different population. J. Stored Prod. Res. 43: 523-528. Proceedings of the 9th International Working Conference for Stored-Product Protection, 15e18 October 2006. ABRAPOS, Campinas, Säo Paulo, Brazil, pp. 789-796. 
Martinazzo, A.P., , L.R.D.A Faroni., P.A Berbert,.., and F.P. Reis, (2000). Tilização da fosfina em combinação com o 1009 aculat de 1009 acula no controle de Rhyzopertha dominica (F.). Pesquisa Agropecuária Brasileira 35, 1063-1069.

Mutambuki, K., C.M., Ngatia, J.N., Mbugua, and P.,Likhayo, (2002). Evaluation of the efficacy of spinosad dust against major storage insect pests. In: Credland, P.F., Armitage, D.M., Bell, C.H., Cogan, P.M., Highley, E. (Eds.), Proceedings of the 8th International Working Conference on Stored-Product Protection, July 22-26, 2002, York, UK. CAB International, Wallington, Oxon, pp. 888-891.

Olivero-Verbel, J., L.S. Nerio, and E.E., Stashenko (2010). Bioactivity against Tribolium castaneum Herbst (Coleoptera: Tenebrionidae) of Cymbopogon maculate and Eucalyptus citriodora essential oils grown in Colombia. Pest Management Science 66, 664-668.

Phillips, T.W., and J.E.,Throne (2010). Biorational approaches to managing stored-product insects. Annual Review of Entomology 55, 375-397.

Salgado, V.L., and T.C., Sparks (2005). The spinosyns: Chemistry, biochemistry, mode of action and resistance. In: Gilbert, L.I., latrou, K., Gill, S. (Eds.), Comprehensive Insect Molecular Science. Elsevier B.V., pp. 137-173. Vol. 6.

Sanon, A., M., Garba, , J.,Auger and J., Huignard (2002). Analysis of the insecticidal activity of methyl iso thio cyanate on Callosobruchus maculatus (F.) (Coleoptera: Bruchidae) and its parasitoid Dinarmus basalis (Rondani) (Hymenoptera: Pteromalidae). Journal of Stored Products Research 38, 129-138.

Sari, L.T., C.S., Ribeiro-Costa, and P.R.V.S., Pereira (2003). Aspectos biológicos de Zabrotes subfasciatus (Bohemann, 1983) (Coleoptera, Bruchidae) em Phaseolus vulgaris L., cv. Carioca (Fabaceae), sob condições de laboratório. Revista Brasileira de Entomologia 47, 621624. SAS Institute, 2001. SAS/Stat User's Guide. SAS, Cary, NC.

Sparks, T.C., G.D., Thompson, H.A., Kirst, M.B., Hertlein, J.S., Mynderse, , J.R., Turner, and T.V., Worden (1999). Fermentation-derived insect control agents. In: Hall, F.R., Menn, J.J. (Eds.), Biopeticides: Use and Delivery. Humana Press, Totowa, pp.171-188.

Subramanyam, Bh., Nelson, J.J., Meronuck, R.A., Flora, E.A., (1999). Evaluation of spinosad on stored-product insects. In: Rossmoore, H.W. (Ed.), Biodeterioration and Biodegradation, Vol. 8. Elsevier, New York, pp. 407 e408.

Subramanya, B.; M. Toews and L. Fang (2003). Spinosad: an effective replacement for organophosphate grain protectants. Advances in stored product protection. Proceedings of the 8th International Working Conference on Stored Product Protection, York, UK, 22-26 July 2002: 2003, 916-920.

Tapondjou, A.L., Adler, C., Fontem, D.A., Bouda, H., Reichmuth, C., 2005. Bioactivities of cymol and essential oils of Cupressus sempervirens and Eucalyptus saligna against Sitophilus zeamais Motschulsky and 
Tribolium confusum du Val. Journal of Stored Products Research 41, 91-102.

Toews, M.D., Bh, Subramanyam, and J., Rowan (2003). Knockdown and mortality of adults of eight species of stored-product beetles exposed to four surfaces treated with spinosad. Journal of Economic Entomology 96, 1967-1973.

تاثير ثلاثة انواع من طرق التطبيق للمبيد الحيوى سبينوسـاد فى مكافحة خنفساء

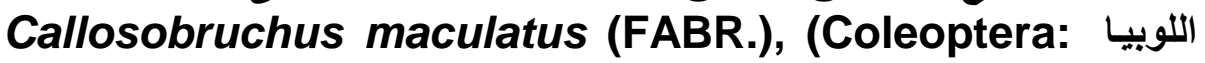
Bruchidae) شريف ابوالقاسم احمد حمادة1 عبير عبدالسلام سـالم محمد2 , ناريمـان محمد عبدالسـلام

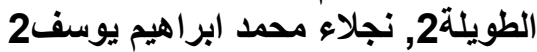

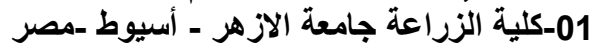

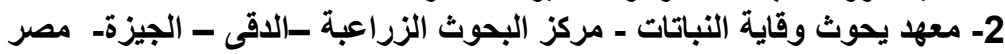

تختلف فاعلية اي مبيد طبقا لطريقة التطبيق, لذا درست ثلاثة طرق تطبيق للمبيد الحيوى سبينوساد (تراسر

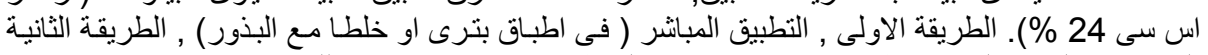

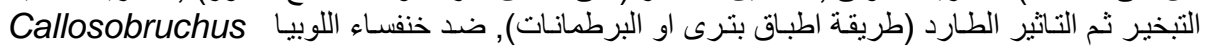
maculatus (FABR.).

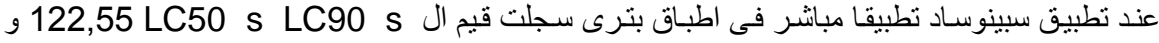

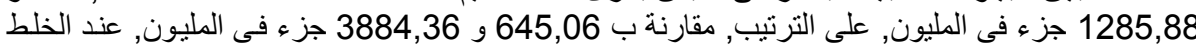

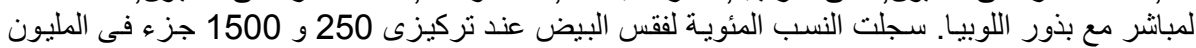

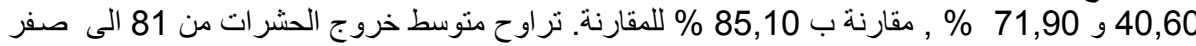

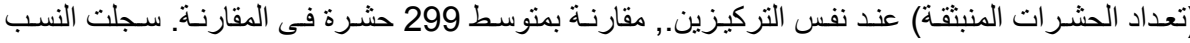

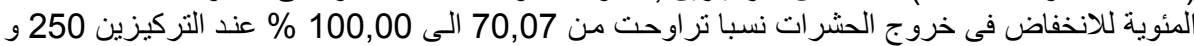

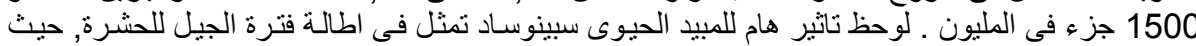

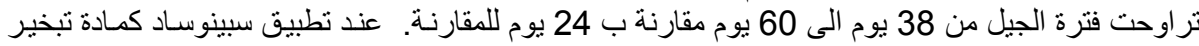

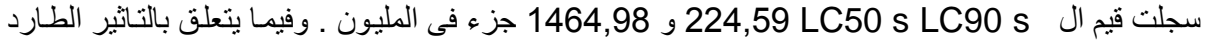

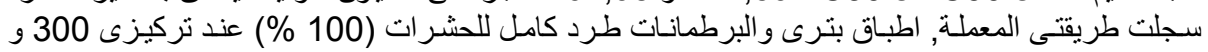

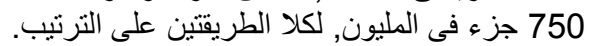
من نتائج الدراسة يمكن ان يمثل المبيد الحيوى سبينوسياد اختيارا جيدا بطريقة التطبيق المباشر للاسطح, حيث تميز بالفاعلية مع وجود صفة هامة كونة الثة مبيد حيوى.

كلية الزراعة - جامعة المنصورة مركز البحوث الزراعيه
قام بتحكيم البحث / أ.د / رافتت يدر ابو عوض عرب اللة 